\title{
Cytogenetic and syntenic assignment of the bovine platelet-activating factor receptor (PTAFR) to cattle chromosome 2 (Brief report)
}

\section{Zytogenetische und synthänische Kartierung des bovinen Platelet-Activating Factor Receptor (PTAFR) auf Rinderchromosom 2 (Brief Report)}

\author{
TOM GOLDAMMER, PETER SCHMIDT and ROSEMARIE WEIKARD
}

Research Unit Molecular Biology, Research Institute for the Biology of Farm Animals, Dummerstorf, Germany

\section{Background}

The platelet-activating factor receptor (PTAFR) encoding gene, also known as PAFR or $P A F r$, belongs to the rhodopsin gene family. The receptor binds the platelet-activating factor (PAF) that has been implicated as a mediator in diverse pathologic processes. In cattle, PTAFR is associated to the reproduction process and is described as a receptor that is involved in inflammatory-like processes of the uterus associated with increased vascular permeability (TIEMANN et al. 2005). The gene sequence was recently annotated on Bos taurus (BTA) chromosome 2 at 129.4 megabases in NCBI Bos taurus build Btau_4.0. The presented data confirm this annotation by independent physical mapping methods and anchor the corresponding DNA segment to the chromosome. PTAFR was assigned by fluorescence in situ hybridization (FISH) and somatic hybrid cell (SHC) mapping.

\section{Material and methods}

Primer sequences for SHC mapping and $B A C$ identification, PTAFR- $F$ 5'-ACC TGG CTG GCT GCT TCTTCT-3' and PTAFR-R 5'-GGG ATG CTG CCC TTC TCG TAA, were designed from the bovine cDNA sequence: Genbank acc. no. AJ295321. Overlapping parts of this bovine CDNA sequence and the actual reference DNA sequence NM_001040538 for PTAFR in cattle NCBI Bos taurus build Btau_4.0 match 100\%.

Pools of the $5 \times$ genome covering bovine BAC library BBI_B750 (ZHU et al. 1999) were received from the former Resource Center of the German Human Genome Project (RZPD, Berlin, Germany) and screened by PCR to obtain a genomic DNA fragment specific bovine specific PTAFR. DNA sequencing of the PCR product was performed to verify the amplification of the bovine PTAFR DNA sequence. Genome database search using the NCBI BLAST tool identified similarity between the bovine PCR product and human genome data. DNA of the identified BAC clone was isolated and purified and used as probe DNA in FISH experiments. Metaphase spreads for FISH were prepared from a cattle embryonic male fibroblast culture by standard cytogenetic techniques. Chromosomes were G-banded by trypsin and Giemsa stained and digitized images of metaphase spreads were applied. Chromosomes were karyotyped according to the ISCNDB 2000 guidelines for bovine G-banded chromosomes (DI BERARDINO et al. 2001). Hybridization 
was performed essentially as described by (PINKEL et al. 1986). Briefly, probes were labeled with biotin-16-dUTP (Roche) by nick-translation. The DNA mixture for FISH was prepared using $0.2 \mu \mathrm{g}$ of the probe, $5 \mu \mathrm{g}$ bovine $\mathrm{C}_{0} \mathrm{t}-1 \mathrm{DNA}$, and $20 \mu \mathrm{g}$ salmon sperm DNA. The analysis of FITC fluorescence signals on propidium iodide colored chromosomes was performed with a fluorescence microscope (Nikon FXA). The overlay of digitized images from the same metaphases prior and after FISH identified the chromosome band with FITC signals.

For SHC mapping, chromosomal assignment of PTAFR has been carried out using a characterized hamster/bovine somatic hybrid cell panel (LAURENT et al. 2000). The PCR reaction in each cell line of the SHC panel was performed in a final volume of $10 \mu \mathrm{l}$ with $100 \mathrm{ng}$ DNA, $10 \mathrm{pmol}$ of each primer, $200 \mu \mathrm{M}$ dNTPs, $0.15 \mathrm{U}$ Taq DNA Polymerase (Promega), and standard enzyme buffer conditions. Samples were initially denatured at $94^{\circ} \mathrm{C}$ for 3 min followed by 35 PCR cycles. Each PCR cycle consisted of denaturation at $95^{\circ} \mathrm{C}$ for $15 \mathrm{sec}$, annealing at $65^{\circ} \mathrm{C}$ for $1 \mathrm{~min}$ and extension at $72^{\circ} \mathrm{C}$ for $15 \mathrm{sec}$. A final elongation step for $7 \mathrm{~min}$ at $72^{\circ} \mathrm{C}$ finished the PCR. PCR products were separated by electrophoresis on agarose gels stained with ethidium bromide.

\section{Results}

PCR screening in the bovine BAC library identified the PTAFR containing DNA fragment in BAC clone B750-L22158Q2. The large fragment clone has been used as probe for FISH and assigned the bovine PTAFR gene to BTA2q45 (Figure1). DNA sequencing of the $277 \mathrm{bp}$ PCR product proved gene specificity. PCR using the PTAFR primers on the SHC panel detected a typical bovine-specific band in 12 of the 39 hybrid cell lines. The data vector obtained was: 110000100000010001000000000100101100111 ( $1=$ present in cell line; $0=$ not present in cell line). A concordance value of 0.94 linked PTAFR to the SHC microsatellite marker CSSM042 and assigned the gene to the BTA2 corresponding synteny group U17.

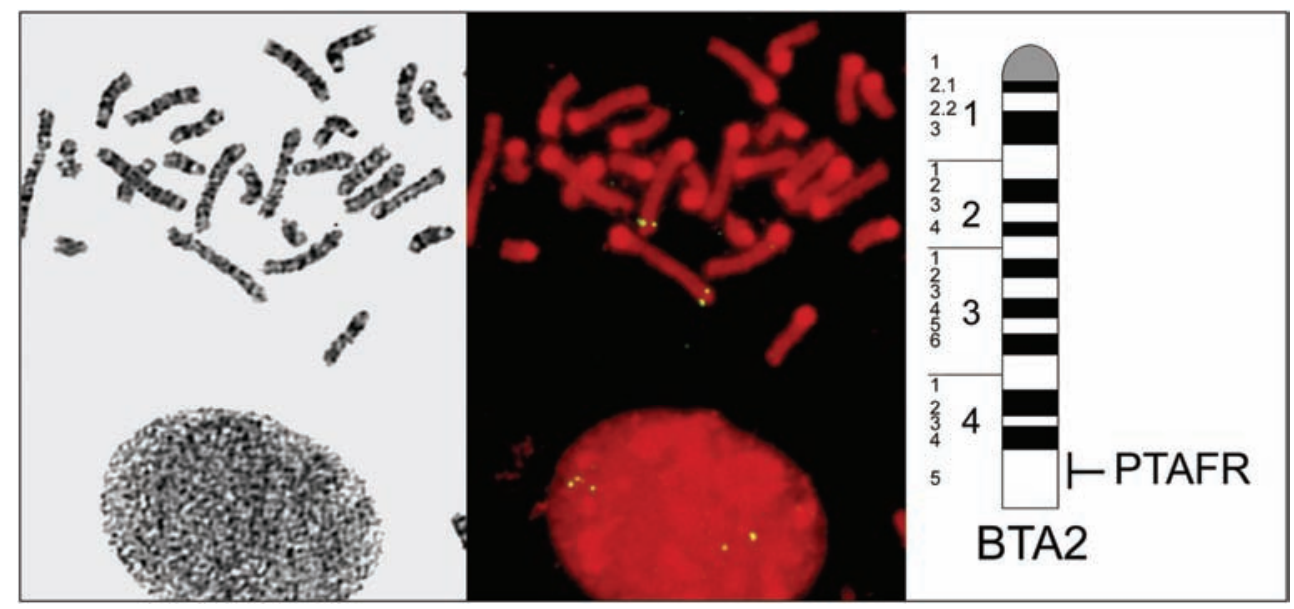

Figure 1

Assignment of PTAFR to cattle chromosome 2q45

Kartierung des PTAFR-Gens auf Rinderchromosom 2q45 
The comparative mapping position of PTAFR in human is on Homo sapiens (HSA) chromosome region HSA1p35-p34.3. Bovine PTAFR is the first comparative cytogenetic anchor that identifies conserved synteny between HSA1p35.3-p34.3 and BTA2q45. Four more genes, RHCE, RHD, ALPI, and CHRND, with described cytogenetic assignments to BTA2q45 have cytogenetic mapping positions on HSA1p36.11 in human (RHCE, RHD) or proximal on HSA2p (ALPI,CHRND), respectively. Thus, the PTAFR locus in cattle is the most distal cytogenetic anchor indicating homology between BTA2 and HSA1.

\section{Acknowledgements}

Supported by grant GO-896/6-3 from the German Research Foundation (DFG). P. Laurent is thankfully acknowledged for providing the SHC panel.

\section{References}

Di Berardino D, Di Meo GP, Hayes H, Gallagher D, lannuzzi L (coordinator) (eds) (2001) ISCNDB (2000): International System for Chromosome Nomenclature of Domestic Bovids. Cytogenet Cell Genet 92, 283-99

Laurent P, Elduque C, Hayes H, Saunier K, Eggen A, Levéziel H (2000) Assignment of 60 human ESTs in cattle. Mamm Genome 11, 748-54

Pinkel D, Straume T, Gray JW (1986) Cytogenetic analysis using quantitative, high-sensitivity, fluorescence hybridization. Proc Natl Acad Sci USA 83, 2934-8

Tiemann U, Bücher K, Pfarrer Ch, Pöhland R, Becker F, Kanitz W, Schmidt P (2005) Influence of ovarian steroid hormones or platelet-activating factor on mRNA of platelet-activating factor receptor in endometrial explant perfusion cultures from ovariectomized bovine. Prostaglandins Other Lipid Mediat 76, 35-47

Zhu B, Smith JA, Tracey SM, Konfortov BA, Welzel K, et al. (1999) A $5 \times$ genome coverage bovine BAC library: production, characterization, and distribution. Mamm Genome 10, 706-9

Received 3 March 2009, accepted 6 May 2009.

Corresponding author:

Dr. TOM GOLDAMMER

email: tomgoldammer@fbn-dummerstorf.de

Forschungsbereich Molekularbiologie, Forschungsinstitut für die Biologie landwirtschaftlicher Nutztiere, Wilhelm-Stahl-Allee 2, 18196 Dummerstorf, Germany 